\title{
Emissions and Secondary Formation of Air Pollutants from Modern Heavy-Duty Trucks in Real-World Traffic-Chemical Characteristics Using On-Line Mass Spectrometry
}

Liyuan Zhou, Christian M. Salvador, Michael Priestley, Mattias Hallquist,* Qianyun Liu, Chak K. Chan,* and Åsa M. Hallquist

Cite This: Environ. Sci. Technol. 2021, 55, 14515-14525

Read Online

ABSTRACT: Complying with stricter emissions standards, a new generation of heavy-duty trucks (HDTs) has gradually increased its market share and now accounts for a large percentage of on-road mileage. The potential to improve air quality depends on an actual reduction in both emissions and subsequent formation of secondary pollutants. In this study, the emissions in real-world traffic from Euro VIcompliant HDTs were compared to those from older classes, represented by Euro V, using high-resolution time-of-flight chemical ionization mass spectrometry. Gas-phase primary emissions of several hundred species were observed for 70 HDTs. Furthermore, the particle phase and secondary pollutant formation (gas and particle phase) were evaluated for a number of HDTs. The reduction in primary emission factors (EFs) was evident ( $90 \%)$ and in line with a reduction of $28-97 \%$ for the typical regulated pollutants. Secondary production of most gas- and particle-phase compounds, for example, nitric acid, organic acids, and carbonyls, after photochemical aging in an oxidation flow reactor exceeded the primary emissions $\left(\mathrm{EF}_{\mathrm{Aged}} / \mathrm{EF}_{\mathrm{Fresh}}\right.$

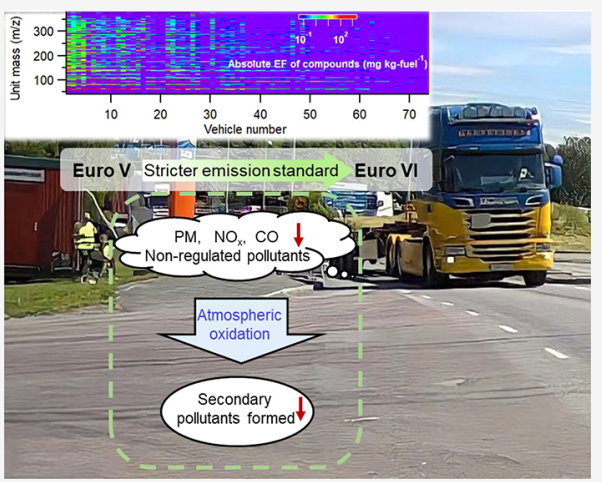
ratio $\geq 2$ ). Byproducts from urea-selective catalytic reduction systems had both primary and secondary sources. A non-negative matrix factorization analysis highlighted the issue of vehicle maintenance as a remaining concern. However, the adoption of Euro VI has a significant positive effect on emissions in real-world traffic and should be considered in, for example, urban air quality assessments.

KEYWORDS: modern vehicle emissions, roadside measurements, secondary pollutants formation, on-line chemical characterization, factor analysis

\section{INTRODUCTION}

Vehicular emissions are a major source of atmospheric pollutants, ${ }^{1,2}$ particularly in urban areas. ${ }^{3,4}$ In recent years, newer heavy-duty vehicles have been operated using more advanced emission control technologies, for example, diesel oxidation catalysts (DOCs) for the oxidation of $\mathrm{CO}$ and hydrocarbons (HC), diesel particulate filters (DPFs) to reduce particulate matter (PM), and selective catalytic reduction (SCR) systems to mitigate $\mathrm{NO}_{x}$. The changes in engine types and emission control systems and a variety of parameters, such as vehicle age, distance, and maintenance, affect vehicle emissions. ${ }^{5-7}$ The implementation of the Euro VI standards in Europe for heavy-duty trucks (HDTs) occurred in late 2012, and Euro VIs accounted for the highest proportion of the total distance traveled (53\%) by HDTs in Sweden in $2018 .{ }^{8}$ Therefore, on-road measurements of the modern in-use fleet are needed to reflect real-world traffic emissions. In our recent study, we reported how this transition might have an impact on typical air pollutants such as PM, black carbon (BC), $\mathrm{NO}_{x}$, and $\mathrm{CO}$. However, the emissions from HDTs do not only contain these traditional air pollutants but many other organic and inorganic compounds as well. Advanced analytical techniques, such as high-resolution time-of-flight chemical ionization mass spectrometry (HR-ToF-CIMS), can be used to further analyze emissions of these compounds from modern vehicles in real traffic. ${ }^{9-11}$ Furthermore, both inorganic and organic primary emissions are susceptible to secondary formation that contributes significantly to poor air quality. ${ }^{1,12,13}$

There is a specific lack of understanding of secondary particle formation from organic gases, that is, secondary organic aerosol (SOA), ${ }^{14}$ meaning that these secondary pollutants from vehicular emissions cannot be regulated directly using current regulations. Smog chambers have been

Received: January 19, 2021

Revised: August 2, 2021

Accepted: September 9, 2021

Published: October 15, 2021

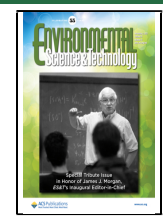


used to increase the understanding of secondary aerosol production from diluted vehicle exhaust. ${ }^{15-17}$ Although the chamber studies can capture secondary aerosol formation from individual vehicles over several hours, they are limited to a small number of tested vehicles, ${ }^{18}$ which may not be representative of the actual in-use vehicle fleets. Alternatively, oxidation flow reactors (OFRs) can be used to assess secondary particle formation from vehicular emissions. ${ }^{18-22}$ For real-world traffic measurement studies using point sampling, OFRs with short response times are well-suited, enabling investigation of a larger number of vehicles, thus capturing the large variability between individual vehicles in a fleet. ${ }^{21}$ The advantage of measurements reflecting real driving conditions for a large number of vehicles is balanced by a reduced possibility to follow individuals/engines under various working conditions (e.g., engine speed and load). However, there are complementary methods that can be used for detailed characterization of various driving cycles, for example, dynamometer tests and onboard sampling. Obviously, these methods are often limited to a small sample size, and there is a challenge to accurately mimic real-world dilution. An optimum method is likely to coherently synthesize information from both approaches to extract synergistic knowledge on emission from vehicle transport systems. In this study, we performed real-world traffic measurements and focused on the in-usetrucks, where we compared the new generation of HDTs (Euro VI compliant) with slightly older models (Euro V compliant). We utilized HR-ToF-CIMS to characterize fresh and aged emissions from both gas and particle phases to reveal important differences and similarities in the transition to a modern HDT fleet. We also investigated the potential to form secondary pollutants using the OFR Gothenburg potential aerosol mass reactor, Go:PAM.

\section{MATERIALS AND METHODS}

Experiments were carried out at an urban roadside site in Gothenburg, Sweden. Extractive sampling of the individual HDT plumes in real traffic was used to characterize the emission, using the method described by Hallquist et al. ${ }^{23}$ More details and description of the experimental conditions can be found in the paper by Zhou et al. ${ }^{24}$ The focus of this study was on using HR-ToF-CIMS and the OFR Go:PAM to analyze the chemical composition and the potential to form secondary pollutants. The schematic of the experimental setup and examples of temporal profiles of pollutant concentrations are shown in Figure S1 (Supporting Information). A camera was placed at the roadside to capture vehicle registration plate numbers, which were then used for further vehicle identification and to obtain engine Euro class information. The HDTs passed the sampling site at an average speed and acceleration of $33 \mathrm{~km} \mathrm{~h}^{-1}$ and $0.9 \mathrm{~km} \mathrm{~h}^{-1} \mathrm{~s}^{-1}$, respectively, on a slight uphill slope $\left(\sim 2^{\circ}\right)$, providing an enhanced engine load. Only plumes from Euro VI and V vehicles were included in the analysis. The criterion for a plume detection was that the $\mathrm{CO}_{2}$ peak concentration should exceed four times the standard deviation of the noise of the background signal. When the Go:PAM or particle characterization inlet was used, the measurements were restricted to times with lower traffic density (more time needed between plumes). Thus, the chemical characterization of the aged emission was performed on separate occasions using HR-ToF-CIMS, while the availability of two engine exhaust particle sizer spectrometer (EEPS, model 3090, TSI Inc., time resolution $10 \mathrm{~Hz}$ ) systems enabled parallel sampling and simultaneous physical particle characterization of both fresh and aged emissions.

2.1. Emission Factor Measurements. A HR-ToF-CIMS system coupled with a Filter Inlet for Gases and AEROsols (FIGAERO) was used to measure both gas phase and particle phase species. A detailed description of the configuration of the instrument can be found elsewhere. ${ }^{25-27}$ Briefly, ambient air was sampled in the ion-molecule region (IMR) at 2.0 standard liters per minute with the species of interest being selectively ionized with reagent ions, that is, Iodide $\left(\mathrm{I}^{-}\right)$. The data were acquired at $1 \mathrm{~s}$ time resolution. The post-mass calibration was fitted to a third order polynomial and for known masses $(\mathrm{m} / z)$ accurate within $3 \mathrm{ppm}: \mathrm{NO}_{2}{ }^{-}, \mathrm{NO}_{3}{ }^{-}, \mathrm{I}^{-}, \mathrm{I} \cdot \mathrm{H}_{2} \mathrm{O}^{-}, \mathrm{I}_{2}^{-}$, and $\mathrm{I}_{3}^{-}$, which covers a range of $46-381 \mathrm{~m} / z$. To estimate absolute emission factors (EFs), a conversion of the CIMS signal to concentration using a sensitivity factor is necessary. Based on the method of Lopez-Hilfiker et al., ${ }^{28}$ the maximum sensitivity (collision-limited) was determined to be $20 \mathrm{~Hz} \mathrm{ppt}^{-1}$, which falls within previously reported ranges. Using the maximum sensitivity provides a lower-limit estimate of EFs for all the oxygenated volatile organic compounds (OVOCs). ${ }^{29}$ One may note that the assumption on sensitivity did not influence the observed relative emission reductions as a result of the change from Euro V to Euro VI or the ratio of aged to fresh emissions. The EFs derived using the FIGAERO were in accordance with Le Breton et al. ${ }^{11}$ Briefly, while conducting the gas-phase sampling/analysis, a particle sample was collected for the duration of the plume on a PTFE filter via a separate inlet. This resulted in a much shorter collection time compared to the typical ambient measurements but is compensated by a higher particle concentration in the HDT plumes. The deposited particles were directly thermally desorbed after the capturing of the plume, and the evaporated vapors were subsequently analyzed by the HR-ToF-CIMS.

The concentration of $\mathrm{CO}_{2}$ was measured with a nondispersive infrared gas analyzer (LI-840A, LI-COR Inc.). $\mathrm{NO}_{x}$ and $\mathrm{NO}$ were measured using two separate chemiluminescent analyzers (model 42i, Thermo Scientific Inc). In addition, CO, NOx, and HC were measured using a remote sensing device (AccuScanTM RSD 5000, OPUS Inspection Inc). Briefly, this instrument generates and monitors a colinear beam of IR- and UV-light passing through the plume. The pollutant concentrations are determined relative to the concentration of $\mathrm{CO}_{2}$ (for more details, see Hallquist et al. $^{23}$ ). Vehicle speed and acceleration were also detected using the RSD. Particle emissions were measured using a high-time resolution EEPS across a size range of $5.6-560 \mathrm{~nm}$. A second EEPS measured the aged particle emissions. Differences in counting efficiencies between the two EEPS were accounted for ${ }^{24}$ and particle wall losses in Go:PAM were corrected using size-dependent transmission efficiencies. ${ }^{21}$ Due to lack of detailed knowledge about the chemical composition and shape of the emitted particles, particle sphericity and unit density were assumed when calculating particle mass. BC was measured using an aethalometer at $880 \mathrm{~nm}$ (model AE33, Magee Scientific Inc).

The EFs of constituents per $\mathrm{kg}$ fuel burnt were calculated by relating the concentration change of a specific compound in the diluted exhaust plume to the change in the $\mathrm{CO}_{2}$ concentration compared to background concentrations ${ }^{21}$ to compensate for different degrees of dilution during sampling. ${ }^{30}$ In the calculation, complete combustion and a carbon content of $86.1 \%$ for diesel fuel were assumed (see details in Supporting Information and the paper by Zhou et al. ${ }^{24}$ ). A 


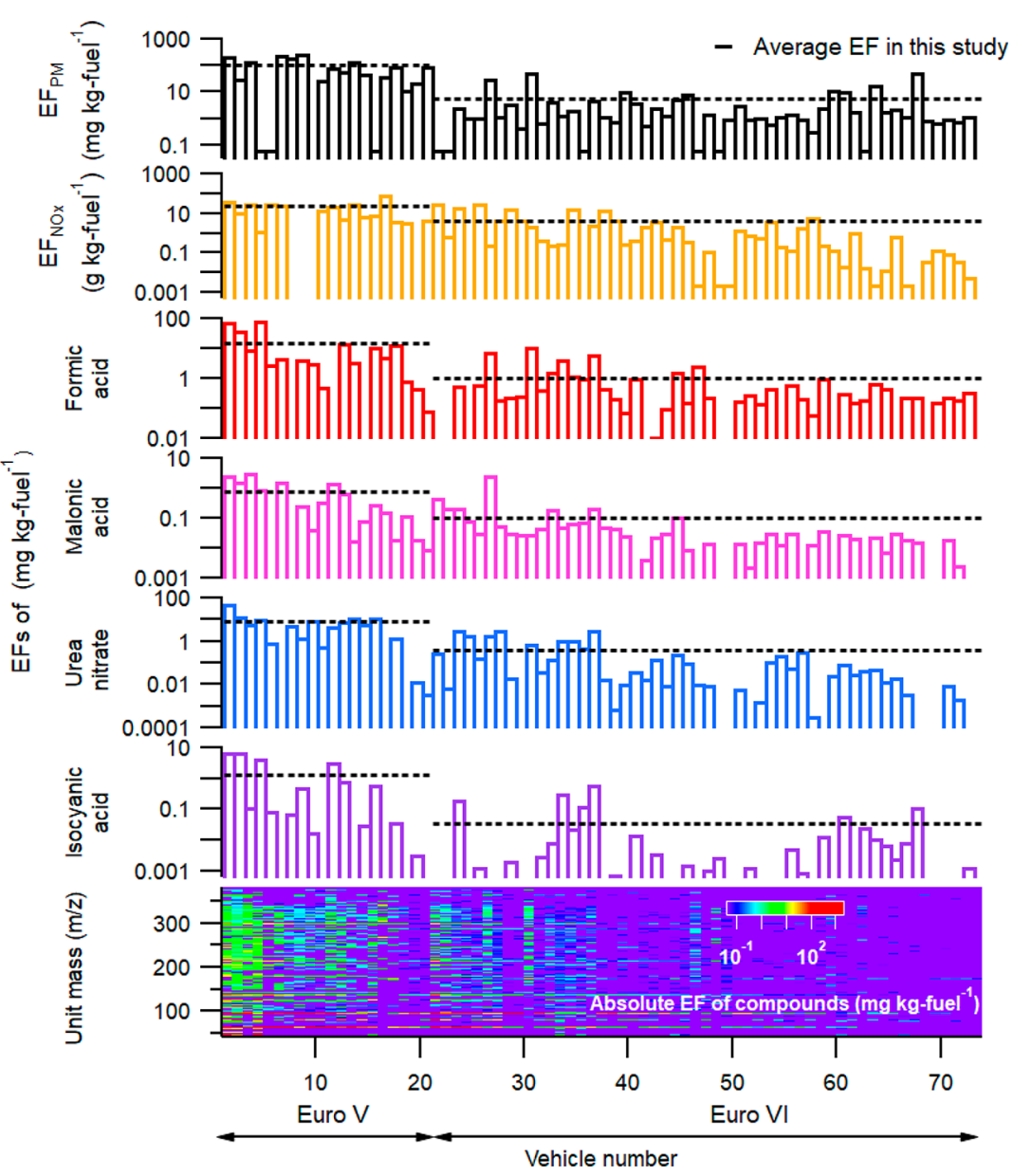

Figure 1. (a) $\mathrm{EF}_{\mathrm{PM}}$, (b) $\mathrm{EF}_{\mathrm{NOx}}$ and $\mathrm{EFs}$ of gaseous (c) formic acid $\left(\mathrm{CH}_{2} \mathrm{O}_{2}\right)$, (d) malonic acid $\left(\mathrm{C}_{3} \mathrm{H}_{4} \mathrm{O}_{4}\right)$, (e) urea nitrate $\left(\mathrm{CH}_{5} \mathrm{~N}_{3} \mathrm{O}_{4}\right)$, and $(\mathrm{f})$ isocyanic acid ( $\mathrm{HNCO}$ ) and respective average EFs (black dashed lines) and (g) EFs of compounds grouped in each unit mass for Euro V and Euro VI compliant Swedish HDTs. Non-detectable pollutant emission signals for captured plumes have been replaced with the corresponding minimum value among all recorded EFs.

discussion on measurement uncertainties and variability of derived EFs is found in Supporting Information.

2.2. Oxidation Flow Reactor Setup. The OFR (Go:PAM) used to study the potential for the formation of secondary gaseous compounds and particle mass has been described in detail elsewhere. ${ }^{21}$ Briefly, the Go:PAM is a $6.1 \mathrm{~L}$ cylindrical continuous-flow quartz glass flow reactor with input flows such that the median residence time is approximately 37 s. The reactor is enclosed by aluminum mirrors to provide homogeneous photon fields. Two Philips TUV $30 \mathrm{~W}$ fluorescent lamps $(\lambda=254 \mathrm{~nm})$ generated $\mathrm{OH}$ radicals through the photolysis of $\mathrm{O}_{3}(\sim 1000 \mathrm{ppb})$ in the presence of water vapor. The relative humidity $(\mathrm{RH})$ in the reactor was 33 $\pm 8 \%(1 \sigma)$ at an ambient temperature of $25 \pm 2{ }^{\circ} \mathrm{C}$. The $\mathrm{O}_{3}$ concentrations and $\mathrm{RH}$ in Go:PAM were measured continuously. The $\mathrm{OH}$ exposure $\left(\mathrm{OH}_{\exp }\right)$ inside the OFR was calibrated offline using $\mathrm{SO}_{2}$ decay, as described by Lambe et al. ${ }^{31}$ During the sampling, the $\mathrm{OH}_{\exp }$ may be significantly influenced by the $\mathrm{OH}$ reactivity of vehicle exhaust and the titration of $\mathrm{O}_{3}$ with NO. ${ }^{10,32,33}$ Thus, the $\mathrm{OH}$ reactivity varies between vehicles, so it was estimated for each truck using the maximum $\mathrm{NO}_{x}, \mathrm{CO}$, and $\mathrm{HC}$ concentrations in the OFR and the corresponding water and ozone concentrations (see details in Supporting Information). ${ }^{21}$ The use of maximum concentrations of these $\mathrm{OH}$ - or $\mathrm{O}_{3}$-consuming species represents a lower, that is, a minimum, estimate of $\mathrm{OH}_{\exp }$ in our calculations. The estimated minimum $\mathrm{OH}_{\text {exp }}$ ranged from 2.0 $\times 10^{9}$ to $2.5 \times 10^{11}$ molecules $\mathrm{cm}^{-3}$ s. Generally, this flowdesign of an OFR enables studies of transient phenomena such as a passing plume. It also works at rather low ozone concentrations (less than $1 \mathrm{ppm}$ ), limiting reactions of other potential oxidants such as $\mathrm{O}_{3}, \mathrm{NO}_{3}$, or $\mathrm{O}^{1} \mathrm{D}$.

\section{RESULTS AND DISCUSSION}

3.1. Fresh Emissions. Figure 1 shows the primary EFs for the particle and gas phase compounds for 18 Euro V and 52 Euro VI compliant HDTs, a subset of the total fleet of 556 HDTs described previously, ${ }^{24}$ and those for which HR-ToFCIMS characterization has been carried out. Two out of the 70 HDTs passed the sampling site more than once, and their emission variabilities were small except for some conditions where there were high levels of dilution (Figure S2). For both Euro V and VI vehicles, the HDT subset had similar average EFs of, for example, particle mass (PM), particle number $(\mathrm{PN}), \mathrm{NO}_{x}$, and $\mathrm{CO}$ as the full data set, being within $\pm 35 \%$. A thorough discussion on the full data set for fresh conditions is found in the article by Zhou et al., ${ }^{24}$ while here the focus is on the results from HR-ToF-CIMS and the aged data.

In general, the EFs of general pollutants (PM, $\mathrm{PN}$, and $\mathrm{NO}_{x}$ ) and of the majority of gaseous compounds detected by HRToF-CIMS were much lower for Euro VI than Euro V (Figure 
Table 1. Average EFs of Selected Gaseous Compounds Measured using HR-ToF-CIMS Complemented with General Pollutants of Euro V and VI Compliant HDTs ${ }^{a}$

\begin{tabular}{|c|c|c|c|c|c|}
\hline formula & compound & Euro V (EF) & \multicolumn{2}{|c|}{ Euro VI (EF) } & reduction from Euro V to VI (\%) \\
\hline \multicolumn{6}{|c|}{ Gaseous Compounds Measured by HR-ToF-CIMS } \\
\hline $\mathrm{CH}_{2} \mathrm{O}_{2}$ & formic acid & $15 \pm 12(4.2)$ & $0.98 \pm 0.60(0.26)$ & mg kg fuel ${ }^{-1}$ & 93 \\
\hline $\mathrm{C}_{3} \mathrm{H}_{6} \mathrm{O}_{3}$ & lactic acid & $14 \pm 10(1.7)$ & $1.1 \pm 0.46(0.42)$ & $\mathrm{mg} \mathrm{kg}$ fuel $^{-1}$ & 92 \\
\hline $\mathrm{C}_{2} \mathrm{H}_{4} \mathrm{O}_{4}$ & dihydroxyacetic acid & $5.5 \pm 5.4^{b}$ & $0.23 \pm 0.16^{b}$ & mg kg fuel ${ }^{-1}$ & 96 \\
\hline $\mathrm{C}_{2} \mathrm{H}_{4} \mathrm{O}_{2}$ & acetic acid & $5.4 \pm 5.5(0.20)$ & $0.21 \pm 0.17(0.005)$ & $\mathrm{mg} \mathrm{kg}$ fuel $^{-1}$ & 96 \\
\hline $\mathrm{C}_{3} \mathrm{H}_{4} \mathrm{O}_{4}$ & malonic acid & $0.73 \pm 0.47(0.23)$ & $0.10 \pm 0.10(0.028)$ & $\mathrm{mg} \mathrm{kg}$ fuel $^{-1}$ & 86 \\
\hline $\mathrm{C}_{3} \mathrm{H}_{6} \mathrm{O}_{2}$ & propionic acid & $0.50 \pm 0.58^{b}$ & $0.013 \pm 0.011^{b}$ & $\mathrm{mg} \mathrm{kg}$ fuel $^{-1}$ & 97 \\
\hline $\mathrm{C}_{4} \mathrm{H}_{8} \mathrm{O}_{2}$ & butyric acid & $0.91 \pm 1.0^{b}$ & $0.013 \pm 0.011^{b}$ & $\mathrm{mg} \mathrm{kg}$ fuel $^{-1}$ & 99 \\
\hline $\mathrm{C}_{5} \mathrm{H}_{8} \mathrm{O}_{3}$ & levulinic acid & $3.4 \pm 2.5(0.78)$ & $0.24 \pm 0.16(0.028)$ & $\mathrm{mg} \mathrm{kg}$ fuel $^{-1}$ & 93 \\
\hline $\mathrm{C}_{7} \mathrm{H}_{6} \mathrm{O}_{2}$ & benzoic acid & $2.2 \pm 1.6(0.39)$ & $0.10 \pm 0.068(0.0072)$ & $\mathrm{mg} \mathrm{kg}$ fuel $^{-1}$ & 95 \\
\hline $\mathrm{C}_{3} \mathrm{H}_{5} \mathrm{NO}_{5}$ & nitrooxypropanoic acid & $1.3 \pm 0.85(0.59)$ & $0.22 \pm 0.19(0.032)$ & $\mathrm{mg} \mathrm{kg}$ fuel $^{-1}$ & 83 \\
\hline $\mathrm{C}_{4} \mathrm{H}_{7} \mathrm{NO}_{5}$ & nitrooxybutanoic acid & $1.6 \pm 0.76(1.2)$ & $0.22 \pm 0.18(0.063)$ & $\mathrm{mg} \mathrm{kg}$ fuel $^{-1}$ & 86 \\
\hline $\mathrm{C}_{5} \mathrm{H}_{9} \mathrm{NO}_{5}$ & nitrooxypentanoic acid & $5.1 \pm 3.8(1.5)$ & $0.79 \pm 0.93(0.094)$ & mg kg fuel ${ }^{-1}$ & 85 \\
\hline $\mathrm{C}_{6} \mathrm{H}_{11} \mathrm{NO}_{5}$ & nitrooxyhexanoic acid & $5.0 \pm 3.1(3.3)$ & $0.91 \pm 1.1(0.08)$ & $\mathrm{mg} \mathrm{kg} \mathrm{fuel}^{-1}$ & 82 \\
\hline $\mathrm{C}_{6} \mathrm{H}_{5} \mathrm{NO}_{4}$ & dihydroxynitrobenzene & $2.1 \pm 1.4(0.98)$ & $0.13 \pm 0.13(0.022)$ & $\mathrm{mg} \mathrm{kg}$ fuel $^{-1}$ & 94 \\
\hline $\mathrm{CH}_{5} \mathrm{~N}_{3} \mathrm{O}_{4}$ & urea nitrate & $8.2 \pm 5.9(5.6)$ & $0.40 \pm 0.25(0.024)$ & $\mathrm{mg} \mathrm{kg} \mathrm{fuel}^{-1}$ & 95 \\
\hline $\mathrm{HNCO}$ & isocyanic acid & $1.3 \pm 1.2(0.061)$ & $0.032 \pm 0.029(0.0008)$ & $\mathrm{mg} \mathrm{kg}$ fuel $^{-1}$ & 98 \\
\hline HONO & nitrous acid & $5.1 \pm 4.2(2.8)$ & $4.1 \pm 4.5(0.25)$ & $\mathrm{mg} \mathrm{kg}$ fuel $^{-1}$ & 20 \\
\hline \multicolumn{2}{|c|}{$\begin{array}{l}\text { non-nitrogen-containing organic species } \\
\text { (carboxylic acids and carbonyl } \\
\text { compounds) }\end{array}$} & $65 \pm 56(9.2)$ & $4.1 \pm 2.7(0.82)$ & $\mathrm{mg} \mathrm{kg}$ fuel $^{-1}$ & 94 \\
\hline \multirow{2}{*}{\multicolumn{2}{|c|}{$\begin{array}{l}\text { acidic nitrogen-containing organic and } \\
\text { inorganic species }\end{array}$}} & $35 \pm 26(16)$ & $7.4 \pm 7.9(0.59)$ & $\mathrm{mg} \mathrm{kg}$ fuel $^{-1}$ & 79 \\
\hline & & & \multicolumn{3}{|c|}{ General Pollutants } \\
\hline & $\mathrm{PM}$ & $102 \pm 47(65)$ & $5.6 \pm 3.4(1.4)$ & $\mathrm{mg} \mathrm{kg} \mathrm{fuel}{ }^{-1}$ & 95 \\
\hline & $\mathrm{PN}$ & $12.3 \pm 6.8(5.4)$ & $8.9 \pm 10.0(0.008)$ & $10^{14} \#_{k g}$ fuel $^{-1}$ & 28 \\
\hline & $\mathrm{BC}$ & $133 \pm 104(37)$ & $3.6 \pm 1.9(0.23)$ & $\mathrm{mg} \mathrm{kg}$ fuel $^{-1}$ & 97 \\
\hline & $\mathrm{NO}_{x}$ & $24 \pm 13(14)$ & $4.1 \pm 2.4(0.55)$ & $\mathrm{g} \mathrm{kg} \mathrm{fuel}^{-1}$ & 83 \\
\hline & $\mathrm{CO}$ & $25 \pm 9.8(24)$ & $15 \pm 2.1(12)$ & $\mathrm{g} \mathrm{kg} \mathrm{fuel}^{-1}$ & 40 \\
\hline & $\mathrm{HC}$ & $0.47 \pm 0.44^{b}$ & $0.92 \pm 0.83^{b}$ & $\mathrm{~g} \mathrm{~kg} \mathrm{fuel}^{-1}$ & \\
\hline
\end{tabular}

${ }^{a}$ Stated errors are at the statistical $95 \%$ confidence interval, representing the variability of the fleet. Median EFs are shown in the parentheses. The compounds selected represent top 10 compounds regarding median EF complemented with compounds discussed in the text. A full list of all assigned compounds is given in Table S1. ${ }^{b}$ Below detection limits.

1). For the lumped sum of identified non-nitrogen-containing carboxylic acids, carbonyl compounds, and nitrogen-containing organic and inorganic compounds, the average EFs were reduced by $79-94 \%$ (Table 1 ). A more extensive list of the changes in EFs for the identified species is shown in the Supporting Information (Table S1). The few pollutants that did not change drastically as a result of moving from Euro $\mathrm{V}$ to Euro VI were HONO (20\% reduction), CO (40\%), and PN (28\%).

The identities of the organic compounds identified by HRToF-CIMS are assigned based on knowledge of sensitivities of the ionization scheme and the expected compounds emitted from the trucks. Plausible structures are assigned from the formulae, with a caveat that other isomers might contribute to the signal. The formulae listed in Table 1 have been assigned to the most plausible structures. A large proportion of the most prominent compounds identified was organic acids. The highest organic acid EFs were observed for formic acid $\left(\mathrm{CH}_{2} \mathrm{O}_{2}\right)$ and lactic acid $\left(\mathrm{C}_{3} \mathrm{H}_{6} \mathrm{O}_{3}\right)$. The average $\mathrm{EF}$ for formic acid for Euro Vs from this study $\left(15 \pm 12 \mathrm{mg} \mathrm{kg} \mathrm{fuel}^{-1}\right)$ falls in between that from a light-duty gasoline fleet $(0.57-0.94 \mathrm{mg} \mathrm{kg}$ fuel $^{-1}$ ) and ocean-going vessels $\left(20.9 \mathrm{mg} \mathrm{kg} \mathrm{fuel}^{-1}\right)^{34}$ and is comparable with the EF reported in an engine dynamometer test $\left(2.8-8.4 \mathrm{mg} \mathrm{kg} \mathrm{fuel}^{-1}\right){ }^{10}$ The average EFs for butyric acid and propanoic acid of Euro V were 0.91 and $0.50 \mathrm{mg} \mathrm{kg} \mathrm{fuel}^{-1}$, respectively, consistent with $0.27-0.76 \mathrm{mg} \mathrm{kg} \mathrm{fuel}^{-1}$ reported by Friedman et al. ${ }^{10}$ Significant reductions (up to 99\%) in the average emissions of all the acids were observed for the Euro VIs in this study (see Tables 1 and S1 for EFs of more compounds).

Urea-type SCR technology is commonly used on HDTs to convert $\mathrm{NO}_{x}$ into nitrogen and water in the presence of a reducing agent, called AdBlue. ${ }^{35}$ We observed average EFs for urea nitrate $\left(\mathrm{CH}_{5} \mathrm{~N}_{3} \mathrm{O}_{4}\right)$ on the order of 8.2 and $0.40 \mathrm{mg} \mathrm{kg}$ fuel $^{-1}$ for Euro Vs and VIs, respectively (Figure 1e). Urea nitrate could be formed as a reaction product of urea with nitric acid $\left(\mathrm{HNO}_{3}\right)$. Isocyanic acid ( $\left.\mathrm{HNCO}\right)$, an intermediate by-product of thermal degradation of urea in the SCR without further sufficient hydrolysis, ${ }^{36}$ was detected at high concentrations in a small number of plumes (e.g., 7.8 and $7.6 \mathrm{mg} \mathrm{kg}$ fuel $^{-1}$ for the two highest emitters in Figure 1f) possibly because it is mostly produced during the start-up/warm-up phase. $^{37,38}$ The average EF for HNCO was $1.3 \mathrm{mg} \mathrm{kg} \mathrm{fuel}^{-1}$ for Euro V HDTs, which is within the range of $0.21-3.96 \mathrm{mg} \mathrm{kg}$ fuel $^{-1}$ for light-duty diesel engine emissions reported by Wentzell et al. ${ }^{39}$ and at the lower end of the reported values of emissions from two SCR-equipped diesel vehicles tested by Suarez-Bertoa and Astorga $\left(1.3-9.7 \mathrm{mg} \mathrm{kg} \mathrm{fuel}^{-1}\right){ }^{40}$ while it is significantly lower than that from a non-road diesel engine with or without after-treatment systems (17-56 mg kg fuel ${ }^{-1}$ ) reported by Jathar et al. ${ }^{41}$ and Link et al. ${ }^{42}$ 
Figure 2 shows the particle-phase pollutant EFs characterized by the FIGAERO ToF-CIMS together with the

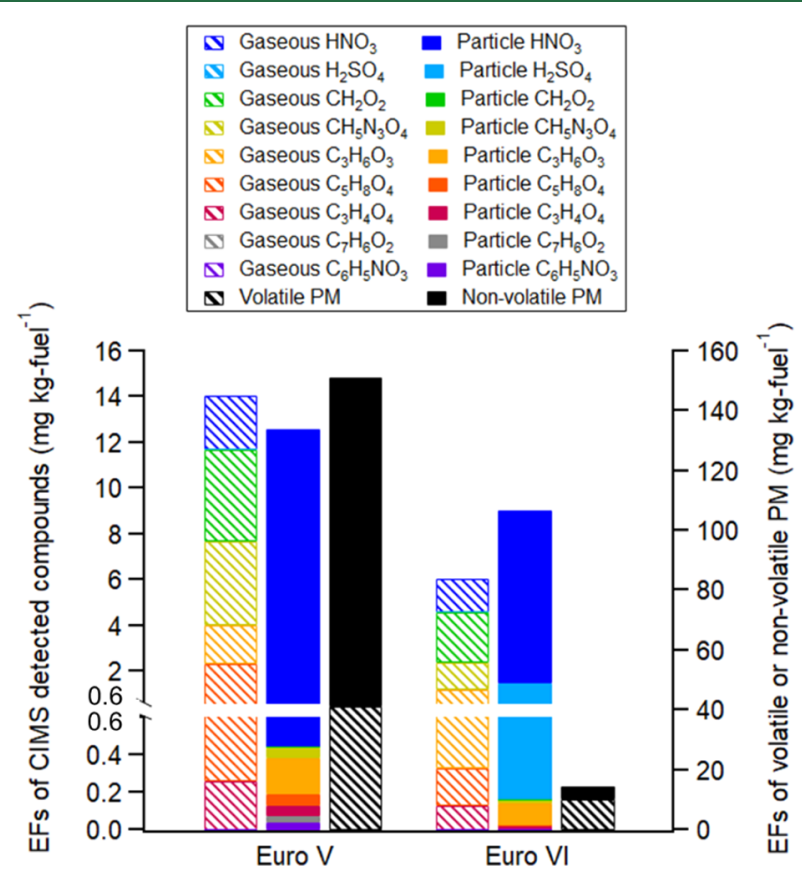

Figure 2. Emissions of gas- and particle-phase CIMS detected compounds, volatile-PM, and non-volatile PM for a Euro V and a Euro VI HDT.

corresponding gas-phase EFs and the EFs of volatile and non-volatile (thermodenuder-conditioned) PMs for a Euro V and a Euro VI HDT (see details on thermodenuder operation and conditions in the article by Zhou et al. ${ }^{24}$ ). This provides a first insight into how the particle-phase composition may change as a result of a full transition from older (Euro V) to newer technology (Euro VI). $\mathrm{HNO}_{3}$ is the most abundant species detected in the particle phase, with an EF of 12.2 and $7.5 \mathrm{mg} \mathrm{kg}$ fuel $^{-1}$ for the Euro V and VI in Figure 2, respectively, considerably higher than $2.5 \mathrm{mg} \mathrm{kg} \mathrm{fuel}^{-1}$ for diesel-fueled buses reported by Le Breton et al. ${ }^{11}$ The slightly reduced $\mathrm{HNO}_{3}$ emissions shown in Figure 2 may be related to the small decrease in $\mathrm{NO}_{2}$ emissions for these HDTs (3.5 and $1.2 \mathrm{~g} \mathrm{~kg} \mathrm{fuel}^{-1}$ for Euro V and Euro VI respectively), while total $\mathrm{NO}_{x}$ emissions for these decreased more significantly from 39 to $4.8 \mathrm{~g} \mathrm{~kg} \mathrm{fuel}^{-1}$. The Euro VI shown in Figure 2 emits $37-68 \%$ less of the individual pollutants measured in the particle phase, than the Euro V. This is similar to the reduction in the emissions of most gaseous species. The reduction of the identified particle-phase species does not correspond to the overall decrease in total PM (90\%) for these two HDTs (Figure 2). The largest reduction is due to the non-volatile fraction (96\%), that is, primarily the soot fraction, which was presumed to be removed efficiently by the DPF. The volatile fraction decreased less drastically (75\%) but still does not match the more modest decrease observed for the characterized species. The selectivity of the iodide ionization scheme may explain the observations where species with low volatility, such as long chain hydrocarbons, cannot be effectively measured. In general, the total $\mathrm{EF}_{\mathrm{CIMS}}$ accounted for a relatively high fraction (88\%) of $\mathrm{EF}_{\text {volatile-PM }}$ for the Euro VI but only $30 \%$ of $\mathrm{EF}_{\text {volatile-PM }}$ for the Euro V.

3.2. Non-negative Matrix Factorization and Hierarchical Clustering Analysis for Fresh Gaseous Emissions. More information about the HDT emissions was obtained by analyzing the huge number of ions measured by HR-ToF-

(a)

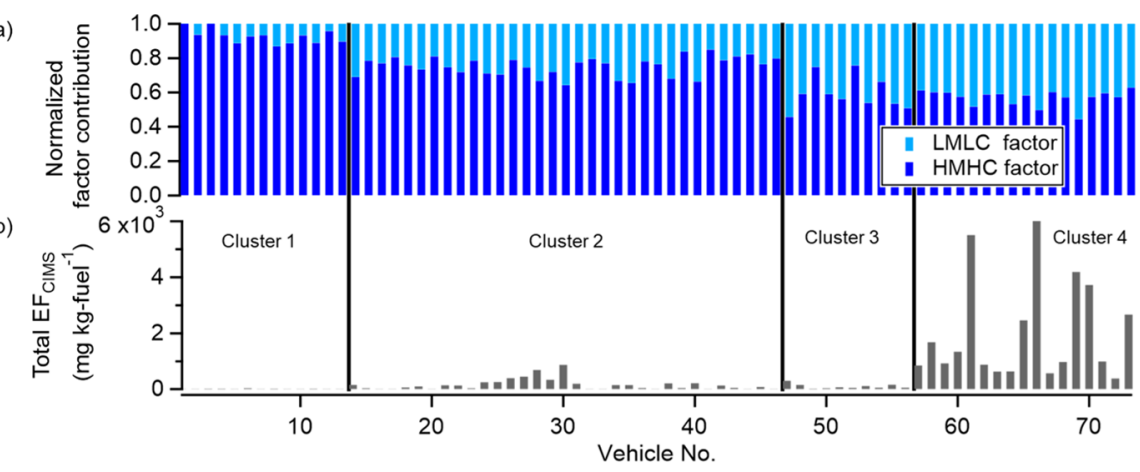

(c)

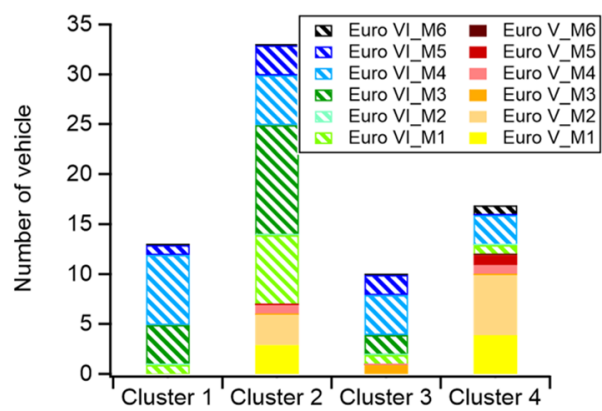

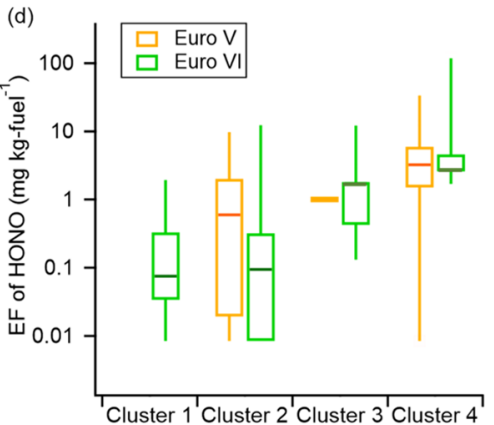

Figure 3. (a) Normalized contribution of HMHC and LMLC factors resolved from the NMF model, (b) EFs of groups of compounds detected by HR-ToF-CIMS, (c) HDTs from different manufacturers clustered by HCA, and (d) EFs of HONO for Swedish Euro V and Euro VI compliant HDTs. Non-detectable pollutant emission signals for captured plumes have been replaced with the corresponding minimum value of all recorded emission factors. For box and whisker plots, the top and the bottom line of the box are 75 and 25 percentiles of the data, respectively, the dark orange and green lines are the medians, and the top and bottom whiskers are 90 and 10 percentiles, respectively. 


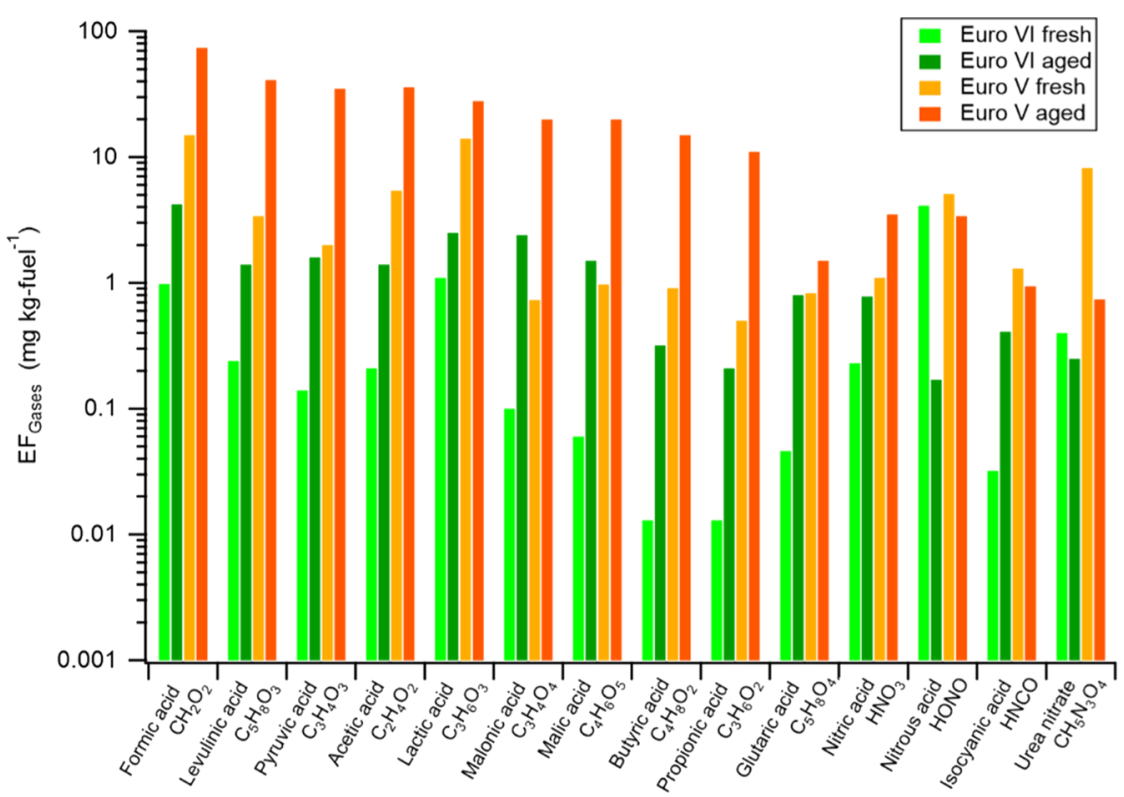

Figure 4. Average fresh and aged gaseous emissions for Euro VI- and V-compliant HDTs.

CIMS. Here, non-negative matrix factorization (NMF) together with hierarchical cluster analysis (HCA) was used to resolve the EFs of the groups of gaseous compounds from the HR-ToF-CIMS spectra (see Supporting Information). The particle phase and aged emissions were excluded because the low sampling number would cause a bias in the evaluation. The analysis was restricted to the 223 ions that had a data coverage of at least $75 \%$ in the 73 passages. From the NMF, two factors were found and designated as a high mass and high carbon (HMHC) factor and a low mass and low carbon (LMLC) factor, with average molecular mass for the top 10 contributing ions of $287 \pm 62(1 \sigma)$ and $93 \pm 33 \mathrm{Th}$, respectively (Figures S5, S6 and Table S2). The vehicle data were clustered by HCA using these two NMF-derived factors as input variables. A fourcluster solution was chosen as it was the simplest yet the most interpretable configuration (Figure S7), describing a mixture of the magnitude of EFs and the fraction of each factor within the clusters (Figure 3a-c). M1-6 represents the six manufacturers of the HDTs. Cluster 1 is characterized by the lowest proportion of the LMLC factor (7.4\% on average) and the lowest total $\mathrm{EF}_{\mathrm{CIMS}}$ and considered as the "cleanest" cluster containing only Euro VI vehicles. Cluster 2 contains a slightly higher proportion of the LMLC factor (25\%) and the largest number of Euro VIs but also some EuroVs. Cluster 3 contains further low total $\mathrm{EF}_{\mathrm{CIMS}}$ but shows an increasing proportion of the LMLC factor ( $41 \%$ on average). Cluster 4 contains mainly Euro Vs, the highest total $\mathrm{EF}_{\mathrm{CIMS}}$, and a similar proportion of the LMLC factor. One possible reason for the pattern of factor distributions and total $\mathrm{EF}_{\mathrm{CIMS}}$ among clusters for vehicles of the same Euro class may be related to the performance of the SCR. Liu et al. ${ }^{43}$ described how a SCR system influences $\mathrm{NO}_{x}$ and low molecular weight organic emissions. HONO was one of the most common contributors to the LMLC factor. The median $\mathrm{EF}_{\mathrm{HONO}}$ for Euro VIs in clusters 1 and 2 was more than $90 \%$ lower than in cluster 3 (Figure 3d). A similar trend is also present for $\mathrm{NO}_{x}$ emissions (Figure S8). Increased proportions of the LMLC factor may indicate SCR deterioration, which is likely to worsen upon further distance traveled. Here, the median distances traveled by Euro VIs in clusters 3 and 4 are more than those in clusters 1 and 2 (Figure S8). To meet more stringent regulations, multiple after-treatment systems (SCR + $\mathrm{DPF})$ are incorporated in Euro VIs, ${ }^{44}$ which may make it more difficult to maintain their optimal operating conditions in realworld traffic. However, no deterioration of DPFs is apparent because the $\mathrm{EF}_{\mathrm{PM}}$ for Euro VIs is similar across different clusters (Mood's median test, $p>0.05$ ) (Figure S8). Euro VIs and Vs cannot be completely separated using NMF analysis likely because of the influence of vehicle deterioration. Therefore, a concern that remains is the issue of maintenance that will become more important in the future when emissions of pollutants during normal operation have decreased significantly.

3.3. Aged Emissions. In total, the aged emissions of 94 HDTs were investigated. The exhaust was oxidized in Go:PAM, and chemical characterization of the aged gaseous pollutants was carried out for 11 HDTs using HR-ToF-CIMS. As with the fresh gaseous emissions, organic acids accounted for a large proportion of the most prominent identified compounds in the aged gaseous emissions, dominated by formic acid $\left(\mathrm{CH}_{2} \mathrm{O}_{2}\right)$ for most of the HDTs (average-aged EFs of formic acid $=4.2 \mathrm{mg} \mathrm{kg}$ fuel ${ }^{-1}$ for Euro VIs and $74 \mathrm{mg} \mathrm{kg}$ fuel $^{-1}$ for a Euro V). For Euro VIs, five out of the six compounds with the highest average-aged $\mathrm{EF}$ were carboxylic acids, of which malonic $\left(\mathrm{C}_{3} \mathrm{H}_{4} \mathrm{O}_{4}\right)$, lactic $\left(\mathrm{C}_{3} \mathrm{H}_{6} \mathrm{O}_{3}\right)$, pyruvic $\left(\mathrm{C}_{3} \mathrm{H}_{4} \mathrm{O}_{3}\right)$, and malic acid $\left(\mathrm{C}_{4} \mathrm{H}_{6} \mathrm{O}_{5}\right)$ were the most dominant. For aged Euro $\mathrm{V}$ emissions, levulinic $\left(\mathrm{C}_{5} \mathrm{H}_{8} \mathrm{O}_{3}\right)$, acetic $\left(\mathrm{C}_{2} \mathrm{H}_{4} \mathrm{O}_{2}\right)$, pyruvic $\left(\mathrm{C}_{3} \mathrm{H}_{4} \mathrm{O}_{3}\right)$, and lactic acid $\left(\mathrm{C}_{3} \mathrm{H}_{6} \mathrm{O}_{3}\right)$ were the most abundant. The EFs of the top six compounds were generally a factor of $\sim 20$ lower for Euro VIs compared to Euro Vs. Also, some nitrogen-containing organic compounds, such as nitrooxybutanoic acid $\left(\mathrm{C}_{4} \mathrm{H}_{7} \mathrm{NO}_{5}\right)$ and nitroacetic acid $\left(\mathrm{C}_{2} \mathrm{H}_{3} \mathrm{NO}_{4}\right)$ were observed among the compounds with the highest-aged EFs (Table S1).

The average-aged gaseous emissions of carboxylic, nitric, and isocyanic acid ranged from two to more than 100 times those of the fresh emissions. However, the emissions of HONO and urea nitrate decreased by $32-96 \%$ after aging (Figure 4). The largest enhancement of aged to fresh emissions of carboxylic acids was observed for malic followed by butyric and malonic acid for Euro VIs. Malonic, propionic, and malic acids yielded 
the largest enhancements for Euro Vs. The secondary production of formic, butyric, and propanoic acid to similar levels has also been observed in previous laboratory chassis dynamometer engine (fueled with diesel) emission tests $\left(0.32-32.1 \mathrm{mg} \mathrm{kg}\right.$ fuel $\left.{ }^{-1}\right){ }^{10}$ Apparently, the photochemical aging of vehicle emissions enhances the importance of small acids originating from heavy-duty traffic.

Upon oxidation, secondary particle mass can be formed. The largest part of the identified secondary PM for Euro VI was due to nitric and sulfuric acid, but carboxylic acids were also significantly present. Three out of five of the most prominent identified compounds were organic acids, which is in line with the aged diesel bus emissions described by Le Breton et al., ${ }^{11}$ and the aged EFs of particle-phase lactic, malonic, and nitric acid were 1-2 orders of magnitude higher than in the fresh emissions (Table S3 and Figure S9).

For each of the 94 HDTs, the total particle mass with and without further oxidation was measured using the EEPS

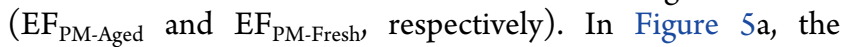
measured $\mathrm{EF}_{\mathrm{PM} \text {-Fresh }}$ and the corresponding $\mathrm{EF}_{\mathrm{PM} \text {-Aged }}$ for Euro VIs and Euro Vs were compared to those reported from a tunnel study ${ }^{18}$ and a roadside measurement of a mixed fleet, ${ }^{22}$ OFR and chamber studies of older diesel, ${ }^{17,21,45-48}$ and biodiesel $^{21}$ and gasoline vehicles. ${ }^{19,49,50}$ For most of the HDTs studied, the particle mass increased when the emissions were oxidized. Around half of the Euro VIs had either $\mathrm{EF}_{\mathrm{PM} \text {-Fresh }}$ or $\mathrm{EF}_{\mathrm{PM} \text {-Aged }}$ lower than the detection limit (denoted by open circles), indicating that either they were clean emitters with $\mathrm{EF}_{\mathrm{PM} \text {-Aged }}$ lower than around $2 \mathrm{mg} \mathrm{kg}$ fuel ${ }^{-1}$ or their primary emissions were too dilute for detection, that is, those with a small $\mathrm{CO}_{2}$-integrated area are found to the left in Figure 5a. The average $\mathrm{EF}_{\mathrm{PM} \text {-Aged }}$ of Euro VIs was approximately $30 \mathrm{mg} \mathrm{kg}$ fuel $^{-1}$, almost 30 times lower compared to that from Euro Vs. However, the median ratio of $\mathrm{EF}_{\mathrm{PM} \text {-Aged }}$ to $\mathrm{EF}_{\mathrm{PM} \text {-Fresh was larger }}$ for Euro VIs (3.3-12.4) than for Euro Vs (2.4). The range for Euro VIs depends on the exclusion or inclusion of HDTs with $\mathrm{EF}_{\mathrm{PM}}$ below the detection limit; hence the ratio can be between 3.3 and 12.4. The $\mathrm{EF}_{\mathrm{PM} \text {-Aged }}$ measurements for Euro VIs in this study were considerably lower than those for Euro III-V diesel- or biodiesel-fueled buses ${ }^{21}$ (100 to $1.7 \times 10^{4} \mathrm{mg}$ $\mathrm{kg} \mathrm{fuel}{ }^{-1}$ ) and heavy-duty or medium-duty diesel vehicles without after-treatment devices ${ }^{45,46}\left(962-3460 \mathrm{mg} \mathrm{kg} \mathrm{fuel}^{-1}\right)$. The $\mathrm{EF}_{\text {Aged-PM }}$ of Euro $\mathrm{V}$ was comparable to that of diesel (or biodiesel)-fueled engines with and without after-treatment devices under $50 \%$ load condition by Jathar et al. ${ }^{47}$ It is noted that idling conditions and cold starts could provide much higher $\mathrm{EF}_{\mathrm{Aged} / \mathrm{PM} \cdot} \cdot{ }^{15,47,51}$ Interestingly, the $\mathrm{EF}_{\mathrm{PM} \text {-Aged }}$ for Euro VIs was also within the range of values for gasoline vehicles compliant to Euro 5, pre-Euro 5, California LEV 2, and preLEV2 standards $\left(1-124 \mathrm{mg} \mathrm{kg} \mathrm{fuel}{ }^{-1}\right) \cdot{ }^{19,49,50}$ It should be noted that the $\mathrm{EF}_{\mathrm{PM} \text {-Fresh }}$ and $\mathrm{EF}_{\mathrm{PM} \text {-Aged }}$ values presented here include both organic and inorganic aerosol masses, while some studies only report the organic fraction. This does not change the conclusion that Euro VIs generate the lowest secondary mass when compared to older diesel vehicles.

The 11 HDTs with the aged gaseous data available, shown with red rectangles in Figure 5a, were analyzed more thoroughly. The secondary particle mass formed $(\Delta \mathrm{PM}=$ $\left.\mathrm{EF}_{\mathrm{PM} \text {-Aged }}-\mathrm{EF}_{\mathrm{PM} \text {-Fresh }}\right)$ and the aged gaseous emissions for these individual HDTs are shown in Figure $5 \mathrm{~b}$. Vehicles $\mathrm{ID}_{1}$ to $\mathrm{ID}_{10}$ were Euro VIs, while Vehicle $\mathrm{ID}_{11}$ was a Euro V. Four of the Euro VIs $\left(\mathrm{ID}_{1,2,7 \& 8}\right)$ had both low-aged gaseous emissions and moderate $\triangle \mathrm{PM}$, indicating that they were fairly clean (a)
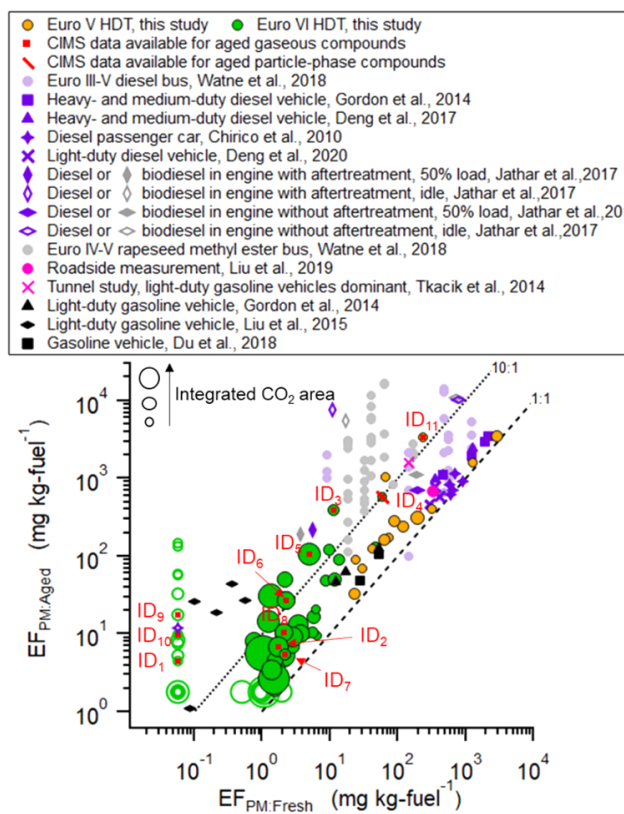

(b)

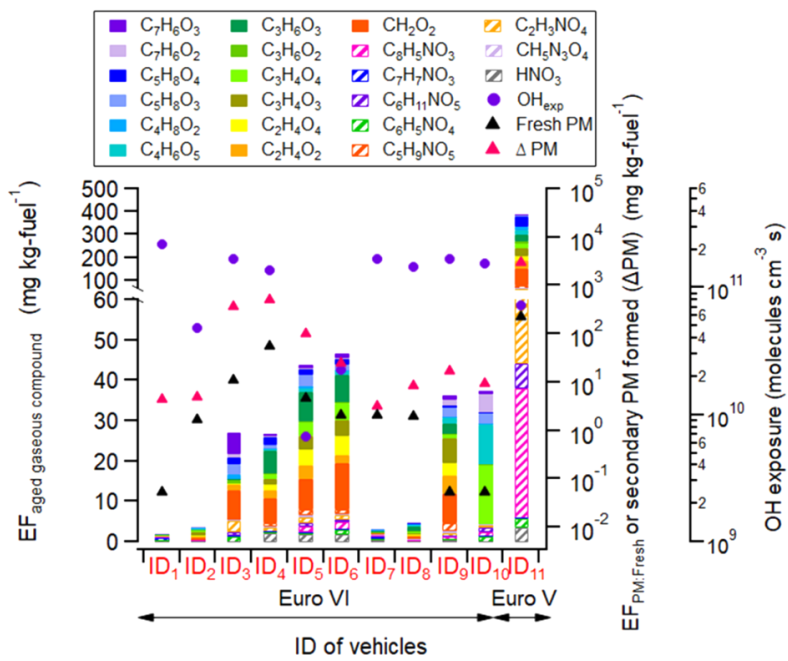

Figure 5. (a) $\mathrm{EF}_{\mathrm{PM} \text { :Aged }}$ vs $\mathrm{EF}_{\mathrm{PM} \text {-Fresh }}$ for Euro V $(\#=14)$ and VI (\# $=80)$ compliant HDTs determined in this study and comparison with that reported from a tunnel study ${ }^{18}$ and a roadside measurement of a mixed fleet (the median EF), ${ }^{22}$ OFR and chamber studies of older diesel, ${ }^{17,21,45-48}$ biodiesel $^{21}$ and gasoline vehicles. ${ }^{19,49,50}$ Pink, purple, grey, and black symbols represent the roadside study, diesel vehicle, biodiesel vehicle, and gasoline vehicle studies, respectively. The red rectangles and slash represent the HDTs with measurements of aged gaseous- and particle-phase pollutants, respectively, determined by the HR-ToF-CIMS. Open markers indicate the HDTs that had either $\mathrm{EF}_{\mathrm{PM} \text {-Fresh }}$ or $\mathrm{EF}_{\mathrm{PM} \text {-Aged }}$ lower than the detection limit. $\mathrm{EF}_{\mathrm{PM} \text {-Aged }}$ and $\mathrm{EF}_{\mathrm{PM}-\mathrm{Fresh}}$ in this study are presented as a function of the dilution level of the plumes (integrated $\mathrm{CO}_{2}$ area, range: 100 to $2 \times 10^{4} \mathrm{ppm} \mathrm{s}$ ). The black dashed lines denote the 1:10 and 1:1 lines. (b) Fresh $\mathrm{EF}_{\mathrm{PM}}$, aged gaseous emissions and secondary particle mass formed $(\triangle \mathrm{PM}=$ $\left.\mathrm{EF}_{\mathrm{PM} \text {-Aged }}-\mathrm{EF}_{\mathrm{PM} \text {-Fresh }}\right)$ for individual HDTs at the respective $\mathrm{OH}_{\text {exp }}$. Table S5 gives the summary of methods used for selected studies. Note that aged gaseous emissions for Euro V-compliant vehicles were derived from one available HDT so are only indicative.

vehicles. The other Euro VIs had substantially higher-aged gaseous emissions with higher and highly variable $\triangle \mathrm{PM}$. The secondary PM formed is dependent on several factors such as the mass of emitted precursors, $\mathrm{OH}_{\text {exp }}$, and the available surface area for the condensational sink. The hydrocarbon 
precursor emission rates, affected by engine load conditions, influence the amount of secondary gaseous pollutants and PM formed. ${ }^{10}$ However, the secondary production of gaseous pollutants and PM can be driven by specific subsets of hydrocarbon precursors and at different time scales. ${ }^{10}$ For two of the Euro VIs $\left(\mathrm{ID}_{5 \& 6}\right)$, the $\mathrm{OH}_{\text {exp }}$ was substantially lower compared to the other Euro VIs, which might explain the lower $\triangle \mathrm{PM}$ formed compared to HDTs $\mathrm{ID}_{3 \& 4}$. For HDTs $\mathrm{ID}_{9}$ and $\mathrm{ID}_{10}$, moderate amounts of aged gaseous compounds were formed but a relatively low secondary PM was produced (compared to $\mathrm{ID}_{3}-\mathrm{ID}_{6}$ ). Here, the freshly emitted particles, which were significantly lower compared to $\mathrm{ID}_{3}-\mathrm{ID}_{6}$, may not provide enough surface area/volume for an efficient partitioning/condensational sink. Compared with other HDTs, $\mathrm{ID}_{10}$ had a slightly different secondary acid profile (dominated by malonic and malic acid), which indicates a different composition of precursors that are less prone to form secondary PM. Consistent with the higher fresh emissions from Euro Vs, $\mathrm{ID}_{11}$ (Euro V) produced the highest amount of aged pollutants including $\triangle \mathrm{PM}$, significantly higher than all the other Euro VIs. The median $\Delta \mathrm{PM}$ values for Euro V and Euro VI vehicles were 111 and $3.2 \mathrm{mg} \mathrm{kg} \mathrm{fuel}^{-1}$, respectively. Thus, a shift to a fleet dominated by Euro VIs would not only result in the reduction in primary pollutant emissions but also be beneficial for mitigating secondary pollutant production including PM and numerous gaseous pollutants.

3.4. Atmospheric Implications. Over the years, the European Union has implemented regulations for heavy-duty vehicles to reduce street-level pollutant concentrations, such as introducing stricter emission standards and substituting traditional diesel fuels with biodiesels. ${ }^{52}$ These regulations target the primary emissions of a few species from a vehicle, while non-regulated compounds and secondary pollutants can also have serious negative impacts on air quality and human health. A question that arises is whether the reduction of compounds targeted in current legislation also reduces other pollutants. From our study, it is evident that this is the case for a majority of the measured primary pollutants and is reflected in the reduction of secondary pollutants as well. However, the reduction of the particle phase has mostly been for the nonvolatile fraction, while the volatile fraction and the compounds investigated using the FIGAERO-ToF-CIMS have been reduced to a lesser degree by the newer technologies. In addition, the risk with some abatement systems is their potential to generate very specific chemical compounds including the by-products from the urea-SCR exhaust systems such as isocyanic acid and urea nitrate. However, these compounds were reduced significantly for Euro VIs, and it is less likely that these, when a full transition to the modern technology has been implemented, will be of great concern. On the contrary, a concern that remains, evident from the NMF analysis, is the issue of maintenance. This will be relatively more important for air quality in the future when the emission of pollutants produced during normal operation has decreased significantly. Another future concern is that once emitted into air, the emissions will be subjected to atmospheric processing, that is, aging. Previous studies have suggested secondary anthropogenic sources of formic, butyric, and propanoic acids. ${ }^{10,53,54}$ These sources have been confirmed along with the additional formation of malonic, malic, and pyruvic acid. Secondary PM formation resulting from exhaust aging was significant for both Euro Vs and VIs (median $\mathrm{EF}_{\mathrm{PM} \text {-Aged }}$ / $\mathrm{EF}_{\mathrm{PM} \text {-Fresh }}$ ratios of 2.4 and 3.3-12.4, respectively). Further- more, an astonishing overall reduction of $90 \%$ in the production of secondary PM for Euro VIs was found, compared to the Euro Vs studied here but also in comparison to the results of previous studies of diesel vehicles. ${ }^{17,21,45,46}$

The effect of a full transition to Euro VI compliancy can be illustrated using the current Swedish fleet. During 2018, the distances driven by Euro V and VI HDTs on Swedish roads were $1.3 \times 10^{9}$ and $2.2 \times 10^{9} \mathrm{~km}$, respectively, accounting for 32 and $53 \%$ of the total distance driven by Swedish diesel HDTs, respectively. The remaining $15 \%$ was attributed to Euro 0-IVs. Based on the average primary EFs (Table 1), the replacement of the current HDT fleet with a fleet consisting exclusively of Euro VIs would reduce the annual primary emissions of non-nitrogen, nitrogen-containing species, and formic acid by 87,64 , and $87 \%$, respectively. However, it will imply only a $10 \%$ reduction in the annual emissions of HONO. In comparison, the emissions of typical combustion pollutants were estimated to decrease annually by $94,93,74,18$, and $6 \%$ for $\mathrm{BC}, \mathrm{PM}, \mathrm{NO}_{x}, \mathrm{CO}$, and $\mathrm{PN}$, respectively. In addition, the aged annual emissions of gaseous non-nitrogen and nitrogencontaining compounds and PM would yield similar reductions of $84-92 \%$ when replacing the fleet. Hence, the adoption of Euro VIs results in a significant reduction in the production of both primary and secondary air pollutants.

\section{ASSOCIATED CONTENT}

\section{SI Supporting Information}

The Supporting Information is available free of charge at https://pubs.acs.org/doi/10.1021/acs.est.1c00412.

Description of NMF and HCA; EF calculations; model calculations of $\mathrm{OH}$ exposure; uncertainty discussion; schematic of the experimental setup; average pollutant EFs; cophenetic correlation coefficients and matrices; HMHC and LMLC factors profiles; carbon number; dendrogram from $\mathrm{HCA} ; \mathrm{EF}_{\mathrm{NO}}, \mathrm{EF}_{\mathrm{PM}}$, and $\mathrm{EF}$; $\mathrm{EF}_{\text {Fresh }}$ and $\mathrm{EF}_{\mathrm{Aged}}$ of $\mathrm{PM}$ contributing species; average EFs of gaseous compounds; top 10 compounds for NMF factors; average fresh and aged EFs; and reaction and rate coefficients (PDF)

\section{AUTHOR INFORMATION}

\section{Corresponding Authors}

Mattias Hallquist - Department of Chemistry and Molecular Biology, University of Gothenburg, 41296 Gothenburg, Sweden; (1) orcid.org/0000-0001-5691-1231; Email: hallq@chem.gu.se

Chak K. Chan - School of Energy and Environment, City University of Hong Kong, Hong Kong, China; 10 orcid.org/ 0000-0001-9687-8771; Email: Chak.K.Chan@ cityu.edu.hk

\section{Authors}

Liyuan Zhou - School of Energy and Environment, City University of Hong Kong, Hong Kong, China; (1) orcid.org/ 0000-0001-8042-6949

Christian M. Salvador - Department of Chemistry and Molecular Biology, University of Gothenburg, 41296 Gothenburg, Sweden; () orcid.org/0000-0002-8328-7777

Michael Priestley - Department of Chemistry and Molecular Biology, University of Gothenburg, 41296 Gothenburg, Sweden 
Qianyun Liu - School of Energy and Environment, City University of Hong Kong, Hong Kong, China

Åsa M. Hallquist - IVL Swedish Environmental Research Institute, 40014 Gothenburg, Sweden; ㅇo이.org/00000001-5092-1615

Complete contact information is available at: https://pubs.acs.org/10.1021/acs.est.1c00412

\section{Notes}

The authors declare no competing financial interest.

\section{ACKNOWLEDGMENTS}

Financial support was from Formas (2013-1430 and 20201907 ) and the framework program "photochemical smog in China”, funded by the Swedish Research Council (2013-6917). C.K.C. and L.Z. acknowledge the National Natural Science Foundation of China (41875142 and 42075100), the ECF Environmental and Conservation Fund (Project 7/2020), and the Guangzhou Development District International Science and Technology Cooperation Project (no. 2018GH08).

\section{REFERENCES}

(1) Gentner, D. R.; Jathar, S. H.; Gordon, T. D.; Bahreini, R.; Day, D. A.; El Haddad, I.; Hayes, P. L.; Pieber, S. M.; Platt, S. M.; de Gouw, J.; Goldstein, A. H.; Harley, R. A.; Jimenez, J. L.; Prévôt, A. S. H.; Robinson, A. L. Review of Urban Secondary Organic Aerosol Formation from Gasoline and Diesel Motor Vehicle Emissions. Environ. Sci. Technol. 2017, 51, 1074-1093.

(2) Dallmann, T. R.; DeMartini, S. J.; Kirchstetter, T. W.; Herndon, S. C.; Onasch, T. B.; Wood, E. C.; Harley, R. A. On-road measurement of gas and particle phase pollutant emission factors for individual heavy-duty diesel trucks. Environ. Sci. Technol. 2012, 46, $8511-8518$.

(3) Sydbom, A.; Blomberg, A.; Parnia, S.; Stenfors, N.; Sandström, T.; Dahlén, S.-E. Health effects of diesel exhaust emissions. Eur. Respir. J. 2001, 17, 733-746.

(4) Nel, A. ATMOSPHERE: Enhanced: Air Pollution-Related Illness: Effects of Particles. Science 2005, 308, 804-806.

(5) El-Fadel, M.; Hashisho, Z. Vehicular emissions in roadway tunnels: a critical review. Crit. Rev. Environ. Sci. Technol. 2001, 31, $125-174$.

(6) Wang, H.; Kawamura, K.; Ho, K. F.; Lee, S. C. Low molecular weight dicarboxylic acids, ketoacids, and dicarbonyls in the fine particles from a roadway tunnel: possible secondary production from the precursors. Environ. Sci. Technol. 2006, 40, 6255-6260.

(7) Liu, Q.; Hallquist, Å. M.; Fallgren, H.; Jerksjö, M.; Jutterström, S.; Salberg, H.; Hallquist, M.; Le Breton, M.; Pei, X.; Pathak, R. K.; Liu, T.; Lee, B.; Chan, C. K. Roadside assessment of a modern city bus fleet: Gaseous and particle emissions. Atmos. Environ.: X 2019, 3, 100044.

(8) HBEFA3.3, http://www.hbefa.net (accessed on May 10, 2021).

(9) Bannan, T. J.; Bacak, A.; Muller, J. B. A.; Booth, A. M.; Jones, B.; Le Breton, M.; Leather, K. E.; Ghalaieny, M.; Xiao, P.; Shallcross, D. E.; Percival, C. J. Importance of direct anthropogenic emissions of formic acid measured by a chemical ionisation mass spectrometer (CIMS) during the Winter ClearfLo Campaign in London, January 2012. Atmos. Environ. 2014, 83, 301-310.

(10) Friedman, B.; Link, M. F.; Fulgham, S. R.; Brophy, P.; Galang, A.; Brune, W. H.; Jathar, S. H.; Farmer, D. K. Primary and secondary sources of gas-phase organic acids from diesel exhaust. Environ. Sci. Technol. 2017, 51, 10872-10880.

(11) Le Breton, M.; Psichoudaki, M.; Hallquist, M.; Watne, Å. K.; Lutz, A.; Hallquist, Å. M. Application of a FIGAERO ToF CIMS for on-line characterization of real-world fresh and aged particle emissions from buses. Aerosol Sci. Technol. 2019, 53, 244-259.
(12) Ning, Z.; Sioutas, C. Atmospheric processes influencing aerosols generated by combustion and the inference of their impact on public exposure: a review. Aerosol Air Qual. Res. 2010, 10, 43-58.

(13) Hallquist, M.; Munthe, J.; Hu, M.; Wang, T.; Chan, C. K.; Gao, J.; Boman, J.; Guo, S.; Hallquist, Å. M.; Mellqvist, J.; Moldanova, J.; Pathak, R. K.; Pettersson, J. B.; Pleijel, H.; Simpson, D.; Thynell, M. Photochemical smog in China: scientific challenges and implications for air-quality policies. Natl. Sci. Rev. 2016, 3, 401-403.

(14) Hallquist, M.; Wenger, J. C.; Baltensperger, U.; Rudich, Y.; Simpson, D.; Claeys, M.; Dommen, J.; Donahue, N. M.; George, C.; Goldstein, A. H.; Hamilton, J. F.; Herrmann, H.; Hoffmann, T.; Iinuma, Y.; Jang, M.; Jenkin, M. E.; Jimenez, J. L.; Kiendler-Scharr, A.; Maenhaut, W.; McFiggans, G.; Mentel, T. F.; Monod, A.; Prévôt, A. S. H.; Seinfeld, J. H.; Surratt, J. D.; Szmigielski, R.; Wildt, J. The formation, properties and impact of secondary organic aerosol: current and emerging issues. Atmos. Chem. Phys. 2009, 9, 5155-5236.

(15) Nordin, E. Z.; Eriksson, A. C.; Roldin, P.; Nilsson, P. T.; Carlsson, J. E.; Kajos, M. K.; Hellén, H.; Wittbom, C.; Rissler, J.; Löndahl, J.; Swietlicki, E.; Svenningsson, B.; Bohgard, M.; Kulmala, M.; Hallquist, M.; Pagels, J. H. Secondary organic aerosol formation from idling gasoline passenger vehicle emissions investigated in a smog chamber. Atmos. Chem. Phys. 2013, 13, 6101-6116.

(16) Weitkamp, E. A.; Sage, A. M.; Pierce, J. R.; Donahue, N. M.; Robinson, A. L. Organic aerosol formation from photochemical oxidation of diesel exhaust in a smog chamber. Environ. Sci. Technol. 2007, 41, 6969-6975.

(17) Chirico, R.; DeCarlo, P. F.; Heringa, M. F.; Tritscher, T.; Richter, R.; Prévôt, A. S. H.; Dommen, J.; Weingartner, E.; Wehrle, G.; Gysel, M.; Laborde, M.; Baltensperger, U. Impact of aftertreatment devices on primary emissions and secondary organic aerosol formation potential from in-use diesel vehicles: results from smog chamber experiments. Atmos. Chem. Phys. Discuss. 2010, 10, 1154511563.

(18) Tkacik, D. S.; Lambe, A. T.; Jathar, S.; Li, X.; Presto, A. A.; Zhao, Y.; Blake, D.; Meinardi, S.; Jayne, J. T.; Croteau, P. L.; Robinson, A. L. Secondary organic aerosol formation from in-use motor vehicle emissions using a potential aerosol mass reactor. Environ. Sci. Technol. 2014, 48, 11235-11242.

(19) Gordon, T. D.; Presto, A. A.; May, A. A.; Nguyen, N. T.; Lipsky, E. M.; Donahue, N. M.; Gutierrez, A.; Zhang, M.; Maddox, C.; Rieger, P.; Chattopadhyay, S.; Maldonado, H.; Maricq, M. M.; Robinson, A. L. Secondary organic aerosol formation exceeds primary particulate matter emissions for light-duty gasoline vehicles. Atmos. Chem. Phys. 2014, 14, 4661-4678.

(20) Timonen, H.; Karjalainen, P.; Saukko, E.; Saarikoski, S.; AakkoSaksa, P.; Simonen, P.; Murtonen, T.; Dal Maso, M.; Kuuluvainen, H.; Bloss, M.; Ahlberg, E.; Svenningsson, B.; Pagels, J.; Brune, W. H.; Keskinen, J.; Worsnop, D. R.; Hillamo, R.; Rönkkö, T. Influence of fuel ethanol content on primary emissions and secondary aerosol formation potential for a modern flex-fuel gasoline vehicle. Atmos. Chem. Phys. 2017, 17, 5311-5329.

(21) Watne, Å. K.; Psichoudaki, M.; Ljungström, E.; Le Breton, M.; Hallquist, M.; Jerksjö, M.; Fallgren, H.; Jutterström, S.; Hallquist, Å. M. Fresh and Oxidized Emissions from In-Use Transit Buses Running on Diesel, Biodiesel, and CNG. Environ. Sci. Technol. 2018, 52, 77207728.

(22) Liu, T.; Zhou, L.; Liu, Q.; Lee, B. P.; Yao, D.; Lu, H.; Lyu, X.; Guo, H.; Chan, C. K. Secondary organic aerosol formation from urban roadside air in Hong Kong. Environ. Sci. Technol. 2019, 53, 3001-3009.

(23) Hallquist, Å. M.; Jerksjö, M.; Fallgren, H.; Westerlund, J.; Sjödin, Å. Particle and gaseous emissions from individual diesel and CNG buses. Atmos. Chem. Phys. 2013, 13, 5337-5350.

(24) Zhou, L.; Hallquist, Å. M.; Hallquist, M.; Salvador, C. M.; Gaita, S. M.; Sjödin, Å.; Jerksjö, M.; Salberg, H.; Wängberg, I.; Mellqvist, J. A transition of atmospheric emissions of particles and gases from on-road heavy-duty trucks. Atmos. Chem. Phys. 2020, 20, $1701-1722$. 
(25) Priestley, M.; Le Breton, M.; Bannan, T. J.; Leather, K. E.; Bacak, A.; Reyes-Villegas, E.; De Vocht, F.; Shallcross, B. M. A.; Brazier, T.; Anwar Khan, M.; Allan, J.; Shallcross, D. E.; Coe, H.; Percival, C. J. Observations of Isocyanate, Amide, Nitrate, and Nitro Compounds From an Anthropogenic Biomass Burning Event Using a ToF-CIMS. J. Geophys. Res.: Atmos. 2018, 123, 7687-7704.

(26) Lee, B. H.; Lopez-Hilfiker, F. D.; Mohr, C.; Kurtén, T.; Worsnop, D. R.; Thornton, J. A. An iodide-adduct high-resolution time-of-flight chemical-ionization mass spectrometer: Application to atmospheric inorganic and organic compounds. Environ. Sci. Technol. 2014, 48, 6309-6317.

(27) Faxon, C.; Hammes, J.; Le Breton, M.; Pathak, R. K.; Hallquist, $\mathrm{M}$. Characterization of organic nitrate constituents of secondary organic aerosol (SOA) from nitrate-radical-initiated oxidation of limonene using high-resolution chemical ionization mass spectrometry. Atmos. Chem. Phys. 2018, 18, 5467-5481.

(28) Lopez-Hilfiker, F. D.; Iyer, S.; Mohr, C.; Lee, B. H.; D’Ambro, E. L.; Kurtén, T.; Thornton, J. A. Constraining the sensitivity of iodide adduct chemical ionization mass spectrometry to multifunctional organic molecules using the collision limit and thermodynamic stability of iodide ion adducts. Atmos. Meas. Tech. 2016, 9, 15051512.

(29) Chen, Y.; Takeuchi, M.; Nah, T.; Xu, L.; Canagaratna, M. R.; Stark, H.; Baumann, K.; Canonaco, F.; Prévôt, A. S. H.; Huey, L. G.; Weber, R. J.; Ng, N. L. Chemical characterization of secondary organic aerosol at a rural site in the southeastern US: insights from simultaneous high-resolution time-of-flight aerosol mass spectrometer (HR-ToF-AMS) and FIGAERO chemical ionization mass spectrometer (CIMS) measurements. Atmos. Chem. Phys. 2020, 20, 84218440.

(30) Janhäll, S.; Hallquist, M. A Novel Method for Determination of Size-Resolved, Submicrometer Particle Traffic Emission Factors. Environ. Sci. Technol. 2005, 39, 7609-7615.

(31) Lambe, A. T.; Ahern, A. T.; Williams, L. R.; Slowik, J. G.; Wong, J. P. S.; Abbatt, J. P. D.; Brune, W. H.; Ng, N. L.; Wright, J. P.; Croasdale, D. R.; Worsnop, D. R.; Davidovits, P.; Onasch, T. B. Characterization of aerosol photooxidation flow reactors: heterogeneous oxidation, secondary organic aerosol formation and cloud condensation nuclei activity measurements. Atmos. Meas. Tech. 2011, $4,445-461$.

(32) Ortega, A. M.; Day, D. A.; Cubison, M. J.; Brune, W. H.; Bon, D.; De Gouw, J. A.; Jimenez, J. L. Secondary organic aerosol formation and primary organic aerosol oxidation from biomass burning smoke in a flow reactor during FLAME-3. Atmos. Chem. Phys. Discuss. 2013, 13, 11551-11571.

(33) Peng, Z.; Day, D. A.; Stark, H.; Li, R.; Lee-Taylor, J.; Palm, B. B.; Brune, W. H.; Jimenez, J. L. HOx radical chemistry in oxidation flow reactors with low-pressure mercury lamps systematically examined by modeling. Atmos. Meas. Tech. 2015, 8, 4863.

(34) Crisp, T. A.; Brady, J. M.; Cappa, C. D.; Collier, S.; Forestieri, S. D.; Kleeman, M. J.; Kuwayama, T.; Lerner, B. M.; Williams, E. J.; Zhang, Q.; Bertram, T. H. On the primary emission of formic acid from light duty gasoline vehicles and ocean-going vessels. Atmos. Environ. 2014, 98, 426-433.

(35) Nova, I.; Tronconi, E.. Urea-SCR Technology for deNO $\mathrm{N}_{x}$ after Treatment of Diesel Exhausts; Springer, 2014; Vol. 5.

(36) Bernhard, A. M.; Peitz, D.; Elsener, M.; Wokaun, A.; Kröcher, O. Hydrolysis and thermolysis of urea and its decomposition byproducts biuret, cyanuric acid and melamine over anatase $\mathrm{TiO} 2$. Appl. Catal., B 2012, 115-116, 129-137.

(37) Cant, N. W.; Chambers, D. C.; Liu, I. O. Y. The reduction of $\mathrm{NO}$ by $\mathrm{CO}$ in the presence of water vapour on supported platinum catalysts: Formation of isocyanic acid (HNCO) and ammonia. Appl. Catal., B 2003, 46, 551-559.

(38) Dümpelmann, R.; Cant, N. W.; Trimm, D. L. The Formation of Isocyanic Acid (HNCO) by Reaction of NO, CO, and H2over Pt/ SiO2and Its Hydrolysis on Alumina. J. Catal. 1996, 162, 96-103.

(39) Wentzell, J. J. B.; Liggio, J.; Li, S.-M.; Vlasenko, A.; Staebler, R.; Lu, G.; Poitras, M.-J.; Chan, T.; Brook, J. R. Measurements of gas phase acids in diesel exhaust: a relevant source of HNCO? Environ. Sci. Technol. 2013, 47, 7663-7671.

(40) Suarez-Bertoa, R.; Astorga, C. Isocyanic acid and ammonia in vehicle emissions. Transp. Res. Part D: Transp. Environ. 2016, 49, 259-270.

(41) Jathar, S. H.; Heppding, C.; Link, M. F.; Farmer, D. K.; Akherati, A.; Kleeman, M. J.; De Gouw, J. A.; Veres, P. R.; Roberts, J. $M$. Investigating diesel engines as an atmospheric source of isocyanic acid in urban areas. Atmos. Chem. Phys. 2017, 17, 8959-8970.

(42) Link, M. F.; Friedman, B.; Fulgham, R.; Brophy, P.; Galang, A.; Jathar, S. H.; Veres, P.; Roberts, J. M.; Farmer, D. K. Photochemical processing of diesel fuel emissions as a large secondary source of isocyanic acid (HNCO). Geophys. Res. Lett. 2016, 43, 4033-4041.

(43) Liu, Z. G.; Berg, D. R.; Swor, T. A.; Schauer, J. J. Comparative analysis on the effects of diesel particulate filter and selective catalytic reduction systems on a wide spectrum of chemical species emissions. Environ. Sci. Technol. 2008, 42, 6080-6085.

(44) Khan, U.; Sen, S.; Dey, S.; Banerjee, A. Development of multi cylinder crd-i engine to meet euro VI emission norms. Int. J. Mech. Eng. Technol. 2016, 7, 26-36.

(45) Deng, W.; Hu, Q.; Liu, T.; Wang, X.; Zhang, Y.; Song, W.; Sun, Y.; Bi, X.; Yu, J.; Yang, W.; Huang, X.; Zhang, Z.; Huang, Z.; He, Q.; Mellouki, A.; George, C. Primary particulate emissions and secondary organic aerosol (SOA) formation from idling diesel vehicle exhaust in China. Sci. Total Environ. 2017, 593-594, 462-469.

(46) Gordon, T. D.; Presto, A. A.; Nguyen, N. T.; Robertson, W. H.; Na, K.; Sahay, K. N.; Zhang, M.; Maddox, C.; Rieger, P.; Chattopadhyay, S.; Maldonado, H.; Maricq, M. M.; Robinson, A. L. Secondary organic aerosol production from diesel vehicle exhaust: impact of aftertreatment, fuel chemistry and driving cycle. Atmos. Chem. Phys. 2014, 14, 4643-4659.

(47) Jathar, S. H.; Friedman, B.; Galang, A. A.; Link, M. F.; Brophy, P.; Volckens, J.; Eluri, S.; Farmer, D. K. Linking load, fuel, and emission controls to photochemical production of secondary organic aerosol from a diesel engine. Environ. Sci. Technol. 2017, 51, 13771386.

(48) Deng, W.; Fang, Z.; Wang, Z.; Zhu, M.; Zhang, Y.; Tang, M.; Song, W.; Lowther, S.; Huang, Z.; Jones, K.; Peng, P. a.; Wang, X. Primary emissions and secondary organic aerosol formation from inuse diesel vehicle exhaust: Comparison between idling and cruise mode. Sci. Total Environ. 2020, 699, 134357.

(49) Liu, T.; Wang, X.; Deng, W.; Hu, Q.; Ding, X.; Zhang, Y.; He, Q.; Zhang, Z.; Lü, S.; Bi, X. Secondary organic aerosol formation from photochemical aging of light-duty gasoline vehicle exhausts in a smog chamber. Atmos. Chem. Phys. 2015, 15, 9049-9062.

(50) Du, Z.; Hu, M.; Peng, J.; Zhang, W.; Zheng, J.; Gu, F.; Qin, Y.; Yang, Y.; Li, M.; Wu, Y.; Shao, M.; Shuai, S. Comparison of primary aerosol emission and secondary aerosol formation from gasoline direct injection and port fuel injection vehicles. Atmos. Chem. Phys. 2018, 18, 9011-9023.

(51) Saliba, G.; Saleh, R.; Zhao, Y.; Presto, A. A.; Lambe, A. T.; Frodin, B.; Sardar, S.; Maldonado, H.; Maddox, C.; May, A. A.; Drozd, G. T.; Goldstein, A. H.; Russell, L. M.; Hagen, F.; Robinson, A. L. Comparison of gasoline direct-injection (GDI) and port fuel injection (PFI) vehicle emissions: emission certification standards, cold-start, secondary organic aerosol formation potential, and potential climate impacts. Environ. Sci. Technol. 2017, 51, 6542-6552.

(52) European Union. Directive 2009/28/EC of the European Parliament and of the Council of 23 April 2009 on the promotion of the use of energy from renewable sources and amending and subsequently repealing Directives 2001/77/EC and 2003/30/EC. Off. J. Eur. Union 2009, 5, 2009.

(53) Veres, P. R.; Roberts, J. M.; Cochran, A. K.; Gilman, J. B.; Kuster, W. C.; Holloway, J. S.; Graus, M.; Flynn, J.; Lefer, B.; Warneke, C. Evidence of rapid production of organic acids in an urban air mass. Geophys. Res. Lett. 2011, 38, L17807.

(54) Yuan, B.; Veres, P. R.; Warneke, C.; Roberts, J. M.; Gilman, J. B.; Koss, A.; Edwards, P. M.; Graus, M.; Kuster, W. C.; Li, S.-M.; Wild, R. J.; Brown, S. S.; Dubé, W. P.; Lerner, B. M.; Williams, E. J.; 
Johnson, J. E.; Quinn, P. K.; Bates, T. S.; Lefer, B.; Hayes, P. L.;

Jimenez, J. L.; Weber, R. J.; Zamora, R.; Ervens, B.; Millet, D. B.;

Rappenglück, B.; de Gouw, J. A. Investigation of secondary formation

of formic acid: urban environment vs. oil and gas producing region.

Atmos. Chem. Phys. 2014, 14, 24863. 